\title{
Characteristics of Beef Sausage Mixed with Modified Bekasam Meat Fermented by Lactobacillus plantarum
}

\author{
G. L. Meristica ${ }^{a}$, J. Gumilar ${ }^{\mathrm{b}}$, \& K. Suradi ${ }^{\mathrm{b}, *}$ \\ ${ }^{a}$ Magister Program in Animal Husbandry, Faculty of Animal Husbandry, Padjadjaran University \\ bepartment of Livestock Production and Technology, Faculty of Animal Husbandry, Padjadjaran University \\ Jalan Raya Sumedang Km. 21 Jatinangor, Sumedang 45363, Indonesia \\ *Corresponding author: kusmajadi@unpad.ac.id \\ (Received 07-02-2020; Revised 22-06-2020; Accepted 01-07-2020)
}

\begin{abstract}
Bekasam is a fermented food from Indonesia that potentially improves the quality of sausage when incorporated in the ingredients. This research was aimed to study the chemical, microbial, and sensory characteristics of sausage made of various concentrations of beef and bekasam meat. The chemical, microbial and sensory characteristics of sausage were investigated using an experimental method in a completely randomized design with 5 treatments, namely T1 $(100 \%$ beef); T2 $(75 \%$ beef + $25 \%$ bekasam meat); T3 ( $50 \%$ beef $+50 \%$ bekasam meat); T4 ( $25 \%$ beef $+75 \%$ bekasam meat); and T5 (100\% bekasam meat). Data analysis of chemical and microbial characteristics was subject to ANOVA and post-hoc Duncan test, while sensory characteristics were analyzed using Kruskal-Wallis test and The Mann-Whitney test. The results showed that the addition of bekasam meat into the sausage mixture significantly $(\mathrm{p}<0.05)$ decreased fat content and sensory characteristics (color, flavor, texture, and overall acceptability). Meanwhile, it increased total bacteria, E. coli and S. aureus inhibition in the sausage. In conclusion, bekasam meat fermented with L. plantarum showed probiotic potentials and could modify beef sausage production.
\end{abstract}

\section{Keywords: Lactobacillus plantarum; fat content; microbial inhibition; sensory; sensory}

\section{INTRODUCTION}

Sausage is a common food across the world. The commonly approved sausage should be chewy, free of synthetic preservatives and coloring agents, and safe for consumption. However, the common meat-based sausage contains a high cholesterol level, which is harmful to human health (Rahardjo, 2003). Incorporating bekasam meat into a sausage mixture is one of the efforts to suppress the high cholesterol content. Also, it diversifies the currently available functional foods.

Bekasam is a popular traditional fish-based fermentation product in several regions in Indonesia, especially East Java, Kalimantan, and Sumatera. Bekasam is made by mixing fish, rice, and salt and fermenting/incubating the mixture in anaerobic conditions. Bekasam can also be made from beef to obtain a higher protein content around 22\% (Ahmad et al., 2018), which is relatively similar to fish, i.e. $18 \%$ (Jag et al., 2018).

The traditionally-made bekasam still lacks uniformity, especially the quality; therefore, incorporating lactic acid bacteria in bekasam fermentation would improve the product. Lactobacillus plantarum is a lactic acid bacteria that is naturally available in beef and capable of producing extracellular protease enzyme. Also, it contains a high affinity and bacteriocin. Bacteriocin produced by LAB is a compound organic acid, such as lactic and acetic acids, and it is safe for consumption (Farinde et al., 2010). Bacteriocin produced during fermentation would also inhibit the growth of pathogens or other harmful microorganisms.

Lactobacillus plantarum has shown a high antibacterial activity towards pathogenic bacteria, both gramnegative and positive bacteria (Zafarullah et al., 2019). Arief et al., (2014) reported that the addition of probiotic L. plantarum IIA-2C12 would increase the physicochemical, microbial, and sensory properties of fermented mutton sausage. Moreover, the antibacterial substrates from L. plantarum 1 BS22 and L. plantarum 1 BL12 would affect the physical and microbial qualities of meat (Afriani et al., 2017). Incorporating L. plantarum into the fermented sausage would improve the taste and aroma as well as inhibiting the growth of pathogenic bacteria compared to the addition of commercial bacteria (Ba et al., 2017). Research on the beef sausage made from fermented bekasam meat is still limited; therefore, the present study investigating the potency of fermented bekasam meat as a functional food by examining the chemical, microbial, and sensory activity. 


\section{MATERIALS AND METHODS}

This experiment used beef from Agro Meat Shop in Bandung and the probiotic culture L. plantarum isolates were obtained from the Academic Leadership Grant (ALG) B 1.13. The Staphylococcus aureus and Escherichia coli were obtained from the Central Laboratory of Padjadjaran University, Jatinangor, Indonesia.

\section{Preparation of Culture Starter}

Lactobacillus plantarum isolates were cultured in an MRSB medium at $37^{\circ} \mathrm{C}$ for 48 hours (Mamta et al., 2017).

\section{Bekasam Preparation}

Bekasam was modified by using beef as the main ingredient. Samples of $300 \mathrm{~g}$ beef shank were washed and cut into $3 \mathrm{~mm}$ pieces and salted (10\% total weight). The beef cutlets were put into a sealed sterile container, added with $300 \mathrm{~g}$ rice and Lactobacillus plantarum starter $20 \%$, then incubated at $37^{\circ} \mathrm{C}$ for 3 days (Zummah \& Wikandari, 2013).

\section{Bekasam Sausage}

The production of bekasam sausage followed a method by Hidayat et al. (2018) with a slight modification. Beef and bekasam were ground in a food processor and added with $12.5 \mathrm{~g}$ ice cube. The ground meat was mixed with $1.5 \mathrm{~g}$ sugar, $6 \mathrm{~g}$ pepper, $1.5 \mathrm{~g}$ nutmeg, $1 \mathrm{~g}$ margarine, $7.5 \mathrm{~g}$ skim milk, $4.5 \mathrm{~g}$ garlic, and $25 \mathrm{~g}$ tapioca flour. The dough was ground and mixed thoroughly until homogenous, put into a sausage casing and weighed. The raw sausage was smoked for 8 hours at $\pm 45^{\circ} \mathrm{C}$. Then, the cooked sausage was examined for chemical, microbial, and sensory quality. The formula of sausage modified with bekasam meat is presented in Table 1.

\section{Chemical Analysis}

The moisture, protein, and fat contents were determined using an analysis of variance (AOAC, 2005).

\section{Microbial Analysis}

Total bacteria. Total bacteria was measured using the total plate count (TPC) method. TPC indicates the total aerobic bacteria in $1 \mathrm{~mL}$ of the sample compared to the standard. The calculation was done by pour plate method when visible colonies were at 25-250. The total bacteria was calculated by the following formula (Maturin \& Peeler, 2001):

$$
\mathrm{N}=\sum \mathrm{c} /\left(\left[\left(1 \times \mathrm{n}_{1}\right)+\left(0.1 \times \mathrm{n}_{2}\right)\right] \times \mathrm{d}\right)
$$

where $\mathrm{N}$ was total colonies/mL of sample, $\sum \mathrm{c}$ was total colonies on all plate (25-250), n1 was total visible colonies on the first dilution, n2 was total visible colonies on the second dilution, and d was firstly calculated dilution/total plate with 25-250 colonies.

Bacteria inhibition. The pathogenic bacteria contamination in this research included Staphylococcus aureus (gram-positive bacteria) and Escherichia coli (gram-negative bacteria). Staphylococcus aureus and Escherichia coli isolates were cultured in a slant nutrient agar for 18 hours. The indicator bacteria were inoculated in $10 \mathrm{~mL}$ nutrient broth and incubated in a shaking water bath at $37^{\circ} \mathrm{C}$ for 18 hours. Then, $20 \mu \mathrm{L}$ bacteria were incorporated into $20 \mathrm{~mL}$ liquid Mueller Hinton Agar (MHA) media at $40^{\circ} \mathrm{C}$. The inoculated liquid MHA media was poured into a sterile petri dish and bacteria inhibition was performed with an agar well diffusion. As reported by Davis \& Stout (1971), bacteria inhibition is indicated from a clear zone around the well, and the diameter of the clear zone is called the inhibitory zone.

Sensory quality. The sensory quality (color, aroma, flavor, texture and overall acceptability) of the sausage

Table 1. Sausage formulation for all treatments

\begin{tabular}{|c|c|c|c|c|c|}
\hline \multirow{2}{*}{ Ingredients } & \multicolumn{5}{|c|}{ Treatments $(\mathrm{g})$} \\
\hline & $\mathrm{T} 1$ & $\mathrm{~T} 2$ & T3 & $\mathrm{T} 4$ & $\mathrm{~T} 5$ \\
\hline Beef & 250 & 187.5 & 125 & 62.5 & 0 \\
\hline Bekasam & 0 & 62.5 & 125 & 187.5 & 250 \\
\hline Ice cube $5 \% *$ & 12.5 & 12.5 & 12.5 & 12.5 & 12.5 \\
\hline Tapioca flour $10 \% *$ & 25 & 25 & 25 & 25 & 25 \\
\hline Skim milk 3\%* & 7.5 & 7.5 & 7.5 & 7.5 & 7.5 \\
\hline Margarine 3\%* & 7.5 & 7.5 & 7.5 & 7.5 & 7.5 \\
\hline \multicolumn{6}{|l|}{ Seasoning ${ }^{* *}$} \\
\hline Salt $2 \%$ & 6 & 6 & 6 & 6 & 6 \\
\hline Sugar $0,5 \%$ & 1.5 & 1.5 & 1.5 & 1.5 & 1.5 \\
\hline Garlic powder $1.5 \%$ & 4.5 & 4.5 & 4.5 & 4.5 & 4.5 \\
\hline Pepper $0.5 \%$ & 1.5 & 1.5 & 1.5 & 1.5 & 1.5 \\
\hline Nutmeg $0.3 \%$ & 1 & 1 & 1 & 1 & 1 \\
\hline Total dough & 317 & 317 & 317 & 317 & 317 \\
\hline
\end{tabular}

Notes: $\mathrm{T} 1=100 \%$ beef; $\mathrm{T} 2=75 \%$ beef $+25 \%$ bekasam meat; $\mathrm{T} 3=50 \%$ beef $+50 \%$ bekasam meat; $\mathrm{T} 4=25 \%$ beef $+75 \%$ bekasam meat; $\mathrm{T} 5=100 \%$ bekasam meat. * weight ingredients of beef; ${ }^{* *}$ total weight of ingredients from the dough (meat, ice cubes, tapioca flour, skim milk and margarine). 
was examined by 20 semi-trained students of the Faculty of Animal Science, Padjajaran University using a hedonic scale ( $1=$ dislike very much, $2=$ dislike, $3=$ dislike slightly, $4=$ like slightly, 5= like, $6=$ like very much, $7=$ like extremely) (Ba et al., 2017).

\section{Data Analysis}

The experiment was conducted in a completely randomized design with 5 treatments, namely T1 (100\% beef); T2 (75\% beef $+25 \%$ bekasam meat); T3 (50\% beef + $50 \%$ bekasam meat); T4 (25\% beef $+75 \%$ bekasam meat); and T5 (100\% bekasam meat). Each treatment was replicated 4 times, and the obtained data were subject to an analysis of variance (ANOVA) followed by Duncan's test to determine differences. The sensory data were analyzed using the non-parametric Kruskal-Wallis test. Also, the Mann-Whitney test was used to differentiate across the means (significance $\mathrm{p}<0.05$ ).

\section{RESULTS}

\section{Chemical Quality of the Sausage}

The chemical analysis (moisture, protein, and fat content) of the sausage is presented in Table 2 . The result showed that incorporating bekasam meat by $25 \%$,
$50 \%, 75 \%$, and $100 \%$ did not affect the moisture and protein content of the sausage compared to control $(100 \%$ beef). However, the fat content significantly decreased $(p<0.05)$ with the addition of bekasam meat.

\section{Microbial Quality of the Sausage}

Total bacteria and bacterial inhibition of the sausage are presented in Table 3. The bacterial inhibition was specifically examined for E. coli and S. aureus. Total bacteria and bacterial inhibition significantly increased with the addition of bekasam meat $(p<0.05)$. However, there was no inhibitory zone in sausage mixed with $0 \%$ and $25 \%$ bekasam meat (Figure 1).

\section{Sensory Quality of the Sausage}

The sensory characteristics of sausage added with bekasam meat are presented in Table 4. The average score for aroma, flavor, texture, and overall acceptability was higher for sausages without bekasam meat. The mean score of aroma for sausage without bekasam meat was 5 , while for sausages that contained $25 \%, 50 \%, 75 \%$, and $100 \%$ bekasam meat were $5,4,5$, and 4, respectively. In contrast, there was no difference in the color of sausage added with bekasam meat.

Table 2. Chemical composition of sausage mixed with modified bekasam meat fermented by Lactobacillus plantarum

\begin{tabular}{lccccc}
\hline \multirow{2}{*}{ Variables } & \multicolumn{5}{c}{ Treatments } \\
\cline { 2 - 6 } & T1 & T2 & T3 & T4 & $62.08 \pm 1.22$ \\
\hline Moisture content (\%) & $61.59 \pm 0.60$ & $63.96 \pm 2.81$ & $64.10 \pm 1.22$ & $61.59 \pm 2.58$ & $13.17 \pm 0.63$ \\
Protein content (\%) & $14.81 \pm 0.14$ & $15.13 \pm 0.24$ & $13.93 \pm 0.17$ & $12.59 \pm 0.27$ & 17 \\
Fat content $(\%)$ & $3.91 \pm 0.34^{\mathrm{a}}$ & $2.85 \pm 0.36^{\mathrm{ab}}$ & $2.94 \pm 0.50^{\mathrm{ab}}$ & $1.03 \pm 0.42^{\mathrm{bc}}$ & $0.57 \pm 0.21^{\mathrm{c}}$ \\
\hline
\end{tabular}

Notes: $\mathrm{T} 1=100 \%$ beef, $\mathrm{T} 2=75 \%$ beef $+25 \%$ bekasam meat, $\mathrm{T} 3=50 \%$ beef $+50 \%$ bekasam meat, $\mathrm{T} 4=25 \%$ beef $+75 \%$ bekasam meat, $\mathrm{T} 5=100 \%$ bekasam meat. Means in the same row with different superscript differ significantly $(\mathrm{p}<0.05)$.

Table 3. Total bacteria and inhibitory zone of sausage added bekasam meat against Escherichia coli and Staphylococcus aureus

\begin{tabular}{lccccc}
\hline \multirow{2}{*}{ Variables } & \multicolumn{5}{c}{ Treatments } \\
\cline { 2 - 6 } & $\mathrm{T} 1$ & $\mathrm{~T} 2$ & $\mathrm{~T} 3$ & $\mathrm{~T} 4$ & $\mathrm{~T} 5$ \\
\hline Total bacteria $\left(\times 10^{7} \mathrm{CFU} / \mathrm{g}\right)$ & $1.06 \pm 0.03^{\mathrm{a}}$ & $2.06 \pm 0.03^{\mathrm{a}}$ & $1.95 \pm 0.05^{\mathrm{a}}$ & $11.33 \pm 0.04^{\mathrm{b}}$ & $21.47 \pm 0.05$ \\
Inhibitory zones $(\mathrm{mm})$ & & & & \\
$\quad$ E. coli & $0 \pm 0^{\mathrm{a}}$ & $0 \pm 0^{\mathrm{a}}$ & $9.57 \pm 1.87^{\mathrm{b}}$ & $9.67 \pm 0.94^{\mathrm{b}}$ & $16.07 \pm 1.44^{\mathrm{c}}$ \\
$\quad$ S. aureus & $0 \pm 0^{\mathrm{a}}$ & $0 \pm 0^{\mathrm{a}}$ & $10.00 \pm 0.62^{\mathrm{b}}$ & $10.57 \pm 1.76^{\mathrm{b}}$ & $17.40 \pm 1.54^{\mathrm{c}}$ \\
\hline
\end{tabular}

Notes: $\mathrm{T} 1=100 \%$ beef, $\mathrm{T} 2=75 \%$ beef $+25 \%$ bekasam meat, $\mathrm{T} 3=50 \%$ beef $+50 \%$ bekasam meat, $\mathrm{T} 4=25 \%$ beef $+75 \%$ bekasam meat, $\mathrm{T} 5=100 \%$ bekasam meat. Means in the same row with different superscript differ significantly $(\mathrm{p}<0.05)$

Table 4. Sensory quality of sausage mixed with modified bekasam meat fermented by Lactobacillus plantarum

\begin{tabular}{|c|c|c|c|c|c|}
\hline \multirow{2}{*}{ Variables } & \multicolumn{5}{|c|}{ Treatments } \\
\hline & $\mathrm{T} 1$ & $\mathrm{~T} 2$ & T3 & $\mathrm{T} 4$ & T5 \\
\hline Color & $5 \pm 1.32^{\mathrm{a}}$ & $5 \pm 1.21^{\mathrm{a}}$ & $5 \pm 0.69^{a}$ & $4 \pm 1.05^{\mathrm{a}}$ & $4 \pm 1.38^{a}$ \\
\hline Aroma & $5 \pm 1.61^{\mathrm{a}}$ & $5 \pm 1.16^{\mathrm{a}}$ & $4 \pm 1.23^{\mathrm{a}}$ & $5 \pm 1.22^{\mathrm{ab}}$ & $4 \pm 1.27^{b}$ \\
\hline Flavor & $5 \pm 1.38^{a}$ & $4 \pm 1.47^{\mathrm{b}}$ & $2 \pm 1.31^{\mathrm{bc}}$ & $2 \pm 0.87^{c}$ & $3 \pm 0.67^{c}$ \\
\hline Texture & $5 \pm 1.41^{\mathrm{a}}$ & $5 \pm 1.26^{\mathrm{a}}$ & $4 \pm 1.04^{\mathrm{b}}$ & $2 \pm 1.12^{\mathrm{bc}}$ & $2 \pm 1.29 c$ \\
\hline Overall acceptability & $5 \pm 1.05^{\mathrm{a}}$ & $4 \pm 0.99 b$ & $4 \pm 1.08^{c}$ & $3 \pm 1.19^{\mathrm{cd}}$ & $3 \pm 0.88^{d}$ \\
\hline
\end{tabular}

Notes: $\mathrm{T} 1=100 \%$ beef, $\mathrm{T} 2=75 \%$ beef $+25 \%$ bekasam meat, $\mathrm{T} 3=50 \%$ beef $+50 \%$ bekasam meat, $\mathrm{T} 4=25 \%$ beef $+75 \%$ bekasam meat, $\mathrm{T} 5=100 \%$ bekasam meat. Means in the same row with different superscript differ significantly $(p<0.05)$. 


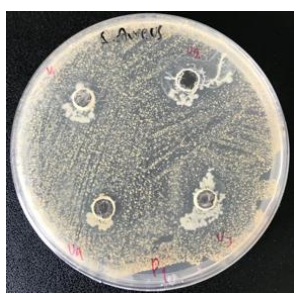

$\mathrm{T} 1$

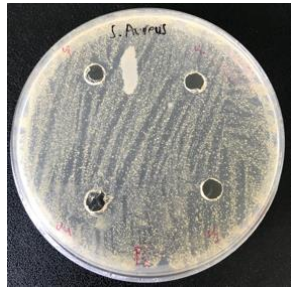

$\mathrm{T} 2$

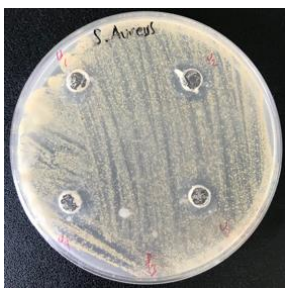

T3

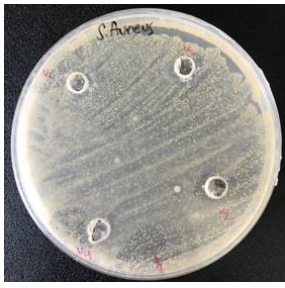

$\mathrm{T} 4$

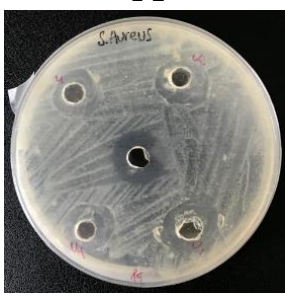

T5

A

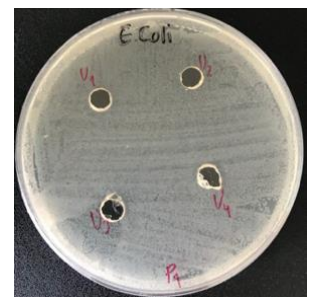

$\mathrm{T} 1$

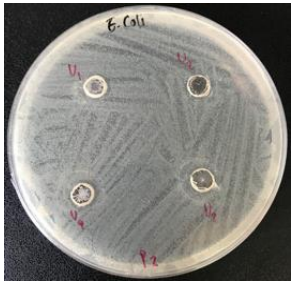

$\mathrm{T} 2$

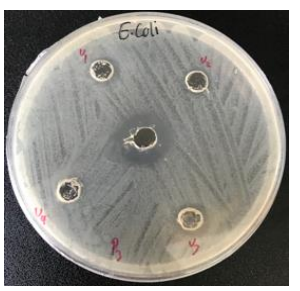

T3

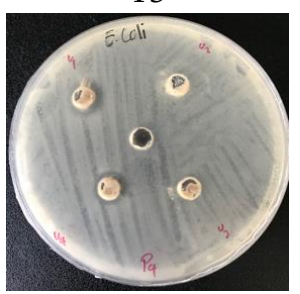

$\mathrm{T} 4$

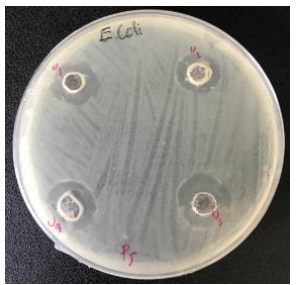

T5

B
Figure 1. Inhibition zone of sausage of all treatment against bacteria (A) Staphylococcus aureus, (B) Escherichia coli.

\section{DISCUSSION}

\section{Chemical Quality of the Sausage}

This study showed that the moisture and protein content of the sausage was not affected ( $p>0.05)$ across treatments because the smoking process evaporates moisture in the sausage for $8 \mathrm{~h}$. According to Askild (2017), a similar smoking time in cooking the sausage would result in similar moisture content in the sausage. Also, modifying sausage with bekasam meat did not affect the protein content because the L. plantarum in bekasam meat produced proteolytic enzyme. Amadou et al. (2011) reported that L. plantarum culture produced proteolytic enzymes that could degrade proteins into simpler proteins. According to Gobbetti et al. (1996), some strains of Lactobacillus produce protease enzymes that could hydrolyze proteins such as casein or gluten with different activities. Despite the differences in the proteolytic activities of L. plantarum, the protein hydrolyzed by protease enzyme is relatively similar (Yusmarini et al., 2010). Regarding sausage quality standards, the Indonesian National Standards (Indonesian National Standards; SNI 01-3820-2015) has determined that the minimum protein and moisture content of beef sausage is $8 \%$ and $67 \%$, respectively. Therefore, regardless of the addition of bekasam meat, the sausage produced in this research conforms to the SNI standard quality.

Incorporating $75 \%$ and $100 \%$ bekasam meat into sausage resulted in a decrease of fat content by $1.03 \%$ and $0.57 \%$, respectively, in comparison with the control. It was in line with Arief et al. (2014) that the presence of L. plantarum significantly reduced the fat content.

In addition, the composition of fat in beef and bekasam meat (in this study) was $7.3 \%$ and $2.83 \%$, respectively. The higher fat content in beef was due to different compositions of fat compared to other types of meat; therefore, beef sausage contained higher fat than bekasam meat. In this study, L. plantarum as one of LAB played a major part in fat formation. Fat content is related to the lipolytic activity of lactic acid bacteria (LAB) during the fermentation process. Lipolytic activity is controlled by the lipase enzyme produced by lactic acid bacteria. It was in accordance with Emine \& Kivanc (2017) that L. plantarum had the highest lipolytic activity compared to other lactic acid bacteria.

\section{Microbiological Analysis}

Total bacteria. Total plate count is the method to analyze all types of non-specific bacteria in the product. In this study, the addition of bekasam meat significantly increased $(p<0.05)$ the total bacteria of sausage. Furthermore, the more bekasam meat added, the higher the total bacteria in the sausage. It was indicative of lactic acid bacteria growth in the fermented meat. L. plantarum has been isolated from various sources, including fermented food across the world, and promoted benefits to human health; accordingly, the products are called potential probiotics (Crowley et al., 2012).

According to Steinkraus (1994) and Fellows (2017), meat is a protein source classified as perishable food that presents pathogenic and non-pathogenic microbes during the fermentation process. The addition of $100 \%$ bekasam meat in beef sausage resulted in the highest of total bacteria value $\left(21.47 \pm 0.05 \times 10^{7} \mathrm{CFU} / \mathrm{g}\right)$ followed by the $75 \%, 50 \%$, and $25 \%$ levels, i.e., $11.33 \pm 0.04$ $\times 10^{7} \mathrm{CFU} / \mathrm{g}, 1.95 \pm 0.05 \times 10^{7} \mathrm{CFU} / \mathrm{g}$, and $2.06 \pm 0.03 \times 10^{7}$ $\mathrm{CFU} / \mathrm{g}$, respectively. It was similar to the previous study (Umam et al., 2019), reporting that the total viable count of microorganisms significantly increased in the fermented goat meat dendeng (mutton jerky) by 5.25 to $6.34 \times 10^{7} \mathrm{CFU} / \mathrm{g}$.

Inhibitory zone. The inhibition of pathogens depends on the rate of nutrients absorption, the inherent metabolic 
velocity, the growth rate, and the excretion of specific inhibitors (Balcázar et al., 2006). The addition of 100\% bekasam meat in sausage demonstrated a strong inhibitory effect against $E$. coli and $S$. aureus with an inhibitory zone value of $16.07 \pm 1.44 \mathrm{~mm}$ and $17.4 \pm 1.54 \mathrm{~mm}$, respectively. In contrast, the inhibitory zone was non-existent in sausage with $0 \%$ and $25 \%$ addition of bekasam meat. Costa et al. (2013) reported that the addition of L. plantarum to bekasam meat produced a higher lactic acid that would inhibit the growth of E. coli and S. aureus. Similarly, Botthoulath et al. (2018) found an inhibitory activity in fermented pork sausage against E. coli DMST 4212 and S. aureus DMST 8840, as the pathogen cell counts fell rapidly by approximately $3 \log$ units at $24 \mathrm{~h}$, and further to below detection limit after $36 \mathrm{~h}$ of incubation.

The production of bekasam meat using grampositive lactic acid bacteria (L. plantarum) would produce a zone of inhibition to the growth of pathogenic bacteria (Gloria et al., 2012; Wang et al., 2018). According to Arief et al. (2014), L. plantarum IIA-2C12 produced an antimicrobial compound that inhibits the growth of pathogenic bacteria and safe to be consumed according to the GSO standard. In addition, the smoking process also contributed to the inhibition of bacterial growth. According to Askild et al. (2017), the bacteriostatic and fungistatic activity from the smoke would inhibit the growth of pathogenic bacteria, such as $E$. coli, Staphylococcus and Pseudomonas. The aliphatic acid and phenolic compounds produced during the smoking process could also inhibit the growth of pathogenic bacteria. Research by Dias et al. (2015) showed that $L$. plantarum had a bacterial inhibition activity against $E$. coli, L. monocytogenes, and S. typhi.

L. plantarum is known to produce higher antibacterial compounds against E. coli, B. cereus, and $L$. monocytogenes (Desniar et al., 2016). The inhibition of Staphylococcus bacteria was due to the lactoline compound, which could also inhibit the growth of $S$. aureus (Davidson \& Hoover, 1993, Wicher et al., 2020). The plantaricin compounds produced by L. plantarum was known to inhibit the growth of $S$. aureus. Another antimicrobial compound produced by lactic acid bacteria that could inhibit the growth of $S$. aureus was hydrogen peroxide (Amro et al., 2018).

\section{Sensory Analysis}

The addition of bekasam meat has significantly decreased $(p<0.05)$ the sensory properties, including aroma, flavor, texture, and overall acceptability, except for color. The similar color across treatments was due to the 8-hour smoking process where phenolic compounds darkened the sausage color. It was in line with Junianingsih et al. (2014) that the changing color of smoked fish was due to the reaction of phenolic compounds to protein and sugar during smoking. Moreover, the Maillard reaction between amino acids and sugar in meat is known to contribute to the changing color of sausage.

The aroma of sausage modified with bekasam meat was accepted by the panelists. A similar aroma across treatments was due to the burnt coconut shell charcoal to produce the smoke, while the long smoking process reduced the fat content, which also affected the sausage aroma. This result was confirmed by Widjanarko et al. (2003) that the smoking process would initiate the absorption of smoking compounds into the sausage and resulted in an authentic sausage aroma.

The addition of bekasam meat in sausage produced unfavorable/disliked flavor. The panelists disliked the overall flavor of bekasam-fortified sausage with bekasam meat because of the acidic taste. Also, sausage flavor is affected by other variables, such as ingredients, cooking process, and the starter cultures (Ahmad \& Amer, 2013). In the texture parameter, the addition of bekasam meat in sausage produced unfavorable texture (too soft). Therefore, future improvement is important to increase the acceptability of the sausage added with bekasam meat.

\section{CONCLUSION}

The present study concluded that different levels of bekasam meat in the sausage significantly affected the chemical, microbial, and sensory characteristics, except for water content, protein content, and colors. Bekasam meat fermented using L. plantarum showed probiotic potential and could modify beef sausage production. Further studies need to confirm the quality of food functionality.

\section{CONFLICT OF INTEREST}

The authors declare that there are no conflicts of interest regarding the publication of this paper.

\section{ACKNOWLEDGEMENT}

The author would like to thank the ALG (Academic Leadership Grant) team of Padjadjaran University for funding and supporting this research.

\section{REFERENCES}

Ahmad, R. S., A. Imran, \& M. B. Hussain. 2018. Nutritional Composition of Meat. In: M. S. Arshad. Meat Science and Nutrition. Intechopen, London. P. 61-77. https://doi. org/10.5772/intechopen.77045

Ahmad, S. \& A. Baher. 2013. Sensory quality of fermented sausages as influenced by different combined cultures of lactic acid bacteria fermentation during refrigerated storage. J. Food Process Technol. 202: 1-8. https://doi. org/10.4172/2157-7110.1000202

Afriani, A., A. Arnim, Y. Marlida, \& Y. Yuherman. 2017. Antibacterial potential of proteolytic lactic acid bacteria from bekasam as beef biopreservatif. J. Pert. Ind. 19: 165173. https://doi.org/10.25077/jpi.19.3.161-169.2017

Amadou, I., G. Le, \& S. O. Gbadamosi. 2011. Optimized Lactobacillus plantarum Lp6 solid-state fermentation and proteolytic hydrolysis improve some nutritional attributes of soybean protein meal. J. Food. Biochem. 35: 1686-1694. https://doi.org/10.1111/j.1745-4514.2010.00493.x

Amro, A., H. Abdelmotaal, Z. T. Zhu, J. Fang-Fang, R. Sami, L. Zhang, A. R. Al-Tawaha, \& X. C. Meng. 2018. Potential benefits of Lactobacillus plantarum as probiotic and its advantages in human health and industrial applications: 
A review. Adv. Environ. Biol. 12: 16-27. https://doi. org/10.22587/aeb.2018.12.1.4

AOAC. 2005. Official Methods of Analysis. $18^{\text {th }}$ edn. Assoc. Off. Anal. Chem., Arlington.

Arief, I. I., Z. Wulandari, E. L. Aditia, \& M. Baihaqi. 2014. Physicochemical and microbiological properties of fermented lamb sausage using probiotic Lactobacillus plantarum IIA-2C12 as starter culture. Proc. Envi. Sci. 20: 352-356. https://doi.org/10.1016/j.proenv.2014.03.044

Askild, H., L. Axelsson, A. McLeod., T. M. Rode, \& E. Heir. 2017. Health and safety considerations of fermented sausages. J. Food. Qual. 3: 1-25. https://doi.org/10.1155/2017/9753894

Ba, H.V., H. W. Seo, S. H. Cho, Y. S. Kim, J. H. Kim, B.Y. Park, H.W. Kim, J. S. Ham, \& P. N. Seong. 2017. Utilization possibility of E. faecalis isolates from neonates feces for production of fermented sausages as starter cultures. Int. J. Food. Sci. Technol. 52: 1660-1669. https://doi.org/10.1111. ijfs. 13440

Badan Standardisasi Nasional. 2015. Standar Nasional Indonesia. SNI 01-3820- 2015. Sosis. Badan Standardisasi Nasional. Jakarta. [28 Juli 2019].

Balcázar, J.L., O. Decamp, D. Vendrell, I. D. Blas, \& I. RuizZarzuela. 2006. Health and nutritional properties of probiotics in fish and shellfish. Microb. Ecol. Health Dis. 18: 65-70. https://doi.org/10.1080/08910600600799497

Botthoulath, V., A. Upaichit, \& U. Thumarat. 2018. Identification and in vitro assessment of potential probiotic characteristics and antibacterial effects of Lactobacillus plantarum subsp. Plantarum SKI19, a bacteriocinogenic strain isolated from Thai fermented pork sausage. J. Food. Sci. Technol. 55: 2774-2785. https://doi.org/10.1007/s13197-018-3201-3

Costa, H. H. S., M. R. Souza, \& L. B. Acurcio. 2013. Probiotic potential of lactic acid bacteria isolated from minas artisanal cheese from Serra da Canastra, MG. Arq. Bras. Med. Vet. Zootec. 65: 1858-1866. https://doi.org/10.1590/ S0102-09352013000600038

Crowley, S., J. Mahony, \& D. Van Sinderen. 2012. Comparative analysis of two antifungal Lactobacillus plantarum isolates and their application as bioprotectants in refrigerated foods. J. Appl. Microbiol. 113: 1417-1427. https://doi. org/10.1111/jam.12012

Davis, W. W. \& T. R. Stout. 1971. Disc Plate Method of Microbiological Antibiotic Assay. Appl. Microbiol. 22: 659-665. https://doi.org/10.1128/AEM.22.4.659-665.1971

Desniar, I. Setyaningsih, \& Y.I. Permana. 2016. Screening and production of antibacterial from Lactobacillus plantarum NS(9) isolated from nila tilapia bekasam. Ind. Fisheries. Processing J. 19: 132-139. https://doi.org/10.17844/jphpi. v19i2.13458

Dias,F.S.,M.R.R.M.Santos, \&R.F.Schwan.2015. Enumeration, identification and safety properties of lactic acid bacteria isolated from pork sausage. Arq. Bras. Med. Vet. Zootec. 67: 918-926. http://dx.doi.org/10.1590/1678-4162-8119

Emine, D. \& M. Kivanc. 2017. Lipolytic activity of lactic acid bacteria isolated from Turkish Pastirma. J. Sci. Technol. C - Life Sci. Biotech. 7: 12-19. https://doi.org/10.18036/ aubtdc.306292

Farinde, E. O., V. A. Obatolu, M. A. Oyarekua, H. A. Adeniran, S.I. Ejoh, \& O. T. Olanipekun. 2010. Physical and microbial properties of fruit flavoured fermented cowmilk and soymilk (yoghurt-like) under different temperature of storage. Afr. J. Food Sci. Technol. 1: 120-127. http://www. interesjournals.org/AJFS

Fellow, P. J. 2017. Food Processing Technology (Fourth Edition).
Woodhead Publishing Series in Food Science, Technology and Nutrition. Pp. 431-512.

Gloria, D., N. B. Omar, H. Abriouel, M. M. Canamero, \& A. Galvez. 2012. Inhibition of Listeria monocytogenes and Escherichia coli by bacteriocin-producing Lactobacillus plantarum EC52 in a meat sausage model system. Afr. J. Microbiol. Res. 6: 1103-1108. https://doi.org/10.5897/ AJMR10.175

Gobbetti, M., E. Smacchi, P. Fox, L. Stepaniak, \& A. Corsetti. 1996. The sourdough microflora. Cellular localization and characterization of proteolytic enzymes in lactic acid bacteria. Food. Sci. Technol. 29: 561-569. https://doi. org/10.1006/fstl.1996.0086

Hidayat, B. T., A. Wea, \& A. Ningrum. 2018. Physicochemical, sensory attributes and protein profile by SDS-PAGE of beef sausage substituted with textured vegetable protein. J. Food. Res. 2: 20-31. https://doi.org/10.26656/ fr.2017.2(1).106

Jag, P., B. N. Shukla, A. K, Maurya, H. O. Verma, G. Pandey, \& Amitha. 2018. A review on role of fish in human nutrition with special emphasis to essential fatty acid. Int. J. Fish. Aquac. 6: 427-430.

Mamta, T., H. W. Deshpande, \& M. A. Bhate. 2017. Isolation and identification of lactic acid bacteria and their exploration in non-dairy probiotic drink. Int. J. Curr. Microbiol. App. Sci. 6:1023-1030. https://doi.org/10.20546/ijcmas.2017.604.127

Maturin, L. \& J. T. Peeler. 2001. Aerobic Plate Count. In: G.J. Jackson, R. Merker, \& R. Bandler (Eds). Food and Drug Administration (FDA), Bacteriological Analytical Manual Online, $8^{\text {th }}$ Edition, Rockville, MD.

Steinkraus, K. H. 1994. Nutritional significance of fermented foods. Food Res. Int. 27: 259-267. https://doi. org/10.1016/0963-9969(94)90094-9

Umam, A. K., L. E. Radiati, A. Susila, \& R. N. Hapsari. 2019. Chemical and microbioogical quality of fermented goat meat dendeng with different levels of $L$. plantarum. IOP Conf. Ser: Earth. Environ. Sci. 387: 1-5. https://doi. org/10.1088/1755-1315/387/1/012012

Wang, L., H. Zhang, M. U. Rehman, K. Mehmood, X. Jiang, M. Iqbal, X. Tong, X. Gao, \& J. Li. 2018. Antibacterial activity of Lactobacillus plantarum isolated from Tibetan yaks. Microb Pathog. 115: 293-298. http://doi.org/10.1016/j. micpath.2017.12.077

Wicher, R. D., A. Junka, J. Paleczny, \& M. Bartoszewicz. 2020. Clinical trials of probiotic strain in selected disease entities. Int. J. Microbiol. 1:1-8. https://doi.org/10.1155/2020/8854119

Widjanarko, S. B., E. Zubaidah, \& A. M. Kusuma. 2003. Study of physical-chemical and organoleptic quality of sausage dombo catfish (Claries gariepinus) due to the effects of boiling, steaming and combination with smoking. J. Tek. Pert. 4: 193-202.

Yusmarini, Y., R. Indrati, \& Y. Marsono. 2010. Proteolytic activities of lactic acid bacteria in fermentation of soymilk. J. Food Sci. Technol. 21: 129-134.

Zafarullah, M., R. Ramzan, A. Abdelazez, A. Amjad, M. Afzaal, S. Zhang, \& S. Pan. 2019. Assessment of the antimicrobial potentiality and functionality of Lactobacillus plantarum strains isolated from the conventional inner mongolian fermented cheese againts foodborne pathogens. J. Pathog. 8:71. https://doi.org/10.3390/pathogens8020071

Zummah, A. \& P. R. Wikandari. 2013. The effect of fermentation time and addition of starter culture of Lactobacillus plantarum B1765 lactic acid bacteria to the quality of milkfish (Chanos chanos) bekasam. UNESA J. Chem. 2: 14-24. 